\title{
STATE FUNDING AND BUDGET EFFICIENCY OF PROGRAM-FOCUSED EVENTS OF REGIONAL INDUSTRY DEVELOPMENT
}

\section{DRŽAVNO FINANSIRANJE I BUDŽETSKA EFIKASNOST PROGRAMSKI FOKUSIRANIH PROGRAMA MERA REGIONALNOG RAZVOJA}

\section{Tatiana A. Paladova}

Maykop State Technological University, Maikop, Russia

\section{Ludmila V. Prigoda}

Maykop State Technological University, Maikop, Russia

\section{Elena S. Maltseva}

Maykop State Technological University, Maikop, Russia

\author{
(C) MESTE NGO \\ JEL Category: 023, R53
}

\begin{abstract}
The article is devoted to topical issues of state funding and budget efficiency of program-focused events of regional industry development. The authors emphasize the need of the public authorities to focus on the generation and efficient use of regulatory instruments governing the procedures and methods of economic relations between business and government.
\end{abstract}

Keywords: state funding, program-focused events, budget efficiency, regional industry, regional socioeconomic system, the state regulatory policy, socio-economic status of the region.

\section{Apstrakt}

Članak je posvećen aktuelnim pitanjima državnog finansiranja i efikasnosti budžeta programskihfokusirana događajima regionalnog razvoja industrije. Autori naglašavaju potrebu rada organa vlasti da se fokusira na generacije $i$ efikasno korišćenje regulatornih instrumenata koji regulišu procedure $i$ metode ekonomskih odnosa biznisa i vlasti.

Adresa autora zaduženog za korespodenciju:
Tatiana Paladova
莑”- tpalad@mail.ru

Ključne reči: državno finansiranje, programskifokusirane mere, efikasnost budžeta, regionalna industrija, regionalni društveno-ekonomski sistem, državna regulatorna politika, društvenoekonomski status regiona 


\section{DISCUSSION}

In modern conditions of regional socio-economic systems, which are characterized by globalization and ambiguous external environmental factors, particularly significant for the increment of the competitive position of the territories as zones of concentration of the productive forces is state regulatory policy. State regulation measures should be aimed at the formation of quality imperatives of dynamic and harmonious development of the reproductive process and enhancing the regional productivity. State regulatory impact on socio-economic processes in regional systems creates incentives and institutional infrastructure development of manufacturing and service sectors of the economy of the region, which, in turn, through the mechanism of transformation of productivity into incomes and effective demand influence the quality of life and consumption of regional population. So now the public authorities need to focus on the generation and efficient use of regulatory instruments governing the procedures and methods of economic relations between business and government. These measures and state regulatory policies are focused on the rapid development of efficient industrial sector of the regional economy as the primary economic relations elements of socio-economic system. That is, the focus should be on generating new and improving old state regulatory measures of industrial policy. Various sources offer different treatments for the concept of industrial policy, which is represented as "state policy and industrial corporations, aimed at the growth of industrial production, ensuring its efficiency and competitiveness, promotion of technical and technological process."

This is the most common interpretation of this concept, which reflects the main purpose of industrial policy. With such a low level of functioning industry as that in Russia its difficult to form and realize any kind of industrial policy. For a long time at the state level one has not accepted any developed projects dealing with industry becoming. Attempts to implement certain ideas in the field of industrial policy existed at the regional level, but they didn't have clear regulatory framework and thus were ineffective. A number of scholars have attempted to offer new tools of innovation and modernization of the industrial sector of regional economy and sub federal territorial associations. However, actuality of formation of effective industrial development measures from the perspective of regional policy and corporate efficiency is maintained.

Until now, there have been discussions regarding the measurement and methodological foundations of scientific understanding of the effectiveness of fiscal measures of state regulatory industrial policy. In our view, the priority should be the public financing of those industries and sectors of the regional economy that form reproductive processes and generate growth in industrial production. In other words, the state should finance the implementation of measures and program-target activities of regional industrial policy. In doing so, the state regulatory measures of industrial policy must be presented from the perspective of efficiency requirements for the regional economy, and from a position of budget efficiency.

The figure shows the sequence of actions of public authorities on the formation of the development strategy of regional industrial complex; the place and role of instruments of state -private partnership in the processing elements of the regulatory state industrial policy is illustrated.

Nowadays the business and public authorities practically integrate their efforts in the development of regional industrial policy. We suggest they interfere their efforts through the formation and implementation of PPP (Public Private Partnership) instruments.

Instruments for implementing and improving industrial policy advocate a set of measures that affect the balance of the industrial potential of sectoral and cross-sectoral proportions.

These measures are aimed at selective state support of certain industries and types of production.

Analysis of the state industrial policy measures allowed us to classify them by level of government (Table 1).

Presented matrix classification divides the main measures of the state industrial policy along one axis into direct and indirect measures of state influence on the industrial potential of the region, 
and on the other axis distributes measures the levels of government. In the framework of this classification one can identify measures for state regional impact on the industrial sector in the region as a set of direct and indirect measures and instruments.

Table 1 Matrix classification of measures of state industrial policy

\begin{tabular}{|c|c|c|c|}
\hline \multicolumn{2}{|c|}{$\begin{array}{l}\text { Classification } \\
\text { criterion }\end{array}$} & \multicolumn{2}{|c|}{ Degree of influence on industrial policy } \\
\hline \multirow{4}{*}{$\begin{array}{l}\bar{\Phi} \\
\frac{\partial}{0} \\
\frac{\Phi}{\pi} \\
\bar{\omega}\end{array}$} & & Indirect measures & Direct measures \\
\hline & Federal & $\begin{array}{l}\text { - Federal taxes and customs dues } \\
\text { - Application of accelerated } \\
\text { depreciation } \\
\text { - Creation of federal innovation } \\
\text { centers }\end{array}$ & $\begin{array}{l}\text { - Innovative financing } \\
\text { - Subsidies from the federal budget } \\
\text { - Providing public guarantees } \\
\text { - Federal government orders }\end{array}$ \\
\hline & Regional & $\begin{array}{l}\text { - Regional tax incentives; } \\
\text { - Creation of industrial parks } \\
\text { - Support for priority investment } \\
\text { projects } \\
\text { - Development of commercial and } \\
\text { industrial chambers of commerce } \\
\text { and industry associations }\end{array}$ & $\begin{array}{l}\text { - Subsidies from the regional budget } \\
\text { - Creation and development of } \\
\text { special economic zones } \\
\text { - Concessions } \\
\text { - Regional government order } \\
\text { - Promotion of regional } \\
\text { investment projects on } \\
\text { Russian and international } \\
\text { forums }\end{array}$ \\
\hline & Municipal & & - Municipal order \\
\hline
\end{tabular}

Table 2 Indicators of the effectiveness of public funding for regional economic development and its industrial sector

\begin{tabular}{|l|l|}
\hline Indicator & Calculation procedure \\
\hline $\begin{array}{l}\text { Effectiveness of state financing measures of } \\
\text { regional economic development (intensive } \\
\text { aspect) }\end{array}$ & $\begin{array}{l}\text { Ratio of regional productivity growth to budget } \\
\text { growth of public financing measures of state } \\
\text { regulatory policy }\end{array}$ \\
\hline $\begin{array}{l}\text { Effectiveness of state financing measures of } \\
\text { regional industry development (extensive } \\
\text { aspect) }\end{array}$ & $\begin{array}{l}\text { Ratio of growth of labor productivity in the } \\
\text { regional industry to the budget growth of state } \\
\text { financing of regional industrial policy measures }\end{array}$ \\
\hline $\begin{array}{l}\text { Effectiveness of state financing measures of } \\
\text { regional economic development (extensive } \\
\text { aspect) }\end{array}$ & $\begin{array}{l}\text { The ratio of gross regional product growth } \\
\text { to the increase in the budget of public financing } \\
\text { of state regulatory policy measures }\end{array}$ \\
\hline $\begin{array}{l}\text { Effectiveness of state financing measures of } \\
\text { regional industry development (intensive aspect) }\end{array}$ & $\begin{array}{l}\text { The ratio of revenue growth of industrial sector } \\
\text { enterprises in the region to the increase in the } \\
\text { budget of state financing of regional industrial } \\
\text { policy measures }\end{array}$ \\
\hline
\end{tabular}

Despite the impact extent both the direct and indirect measures influence (to a different extent though) the development of industry in the region, however, the use of direct measures of state regulatory policy gives much greater effect, since the degree of influence of this group of state regulation on corporate industrial sector is stronger. 
Government effectiveness and regulatory measures of preferential and industrial policies can be measured from the position of increment of the gross regional product and regional productivity. That is, in fact we are talking about measuring the intensive and extensive types of regional economic development under the influence of public-private partnership measures (which, in turn, are generated in the regional industrial policy). Development of the regional economy under the influence of extensive and intensive factors, as well as the effectiveness of public regulation in this circuit can be measured by the following methods (Table 2)
Based on data from this table, there are four main indicators that will characterize not only the budget of regional industrial policy, but also the efficiency of its implementation in four vectors of measurement and observation.

Application of the method of measurement of industrial policy public financing effectiveness in the loop type of regional development (extensive or intensive) will not only answer the question whether effectively or ineffectively one has spent budget funds, but also will contribute to more accurate planning of future measures of state regulation from the perspective of those goals that the state wishes to achieve in the strategic socioeconomic development of the region.
Datum prve prijave:

Datum prijema korigovanog članka:

Datum prihvatanja članka:
04.03.2014.

29.06.2014.

21.06.2015.

\section{Kako citirati ovaj rad? / How to cite this article?}

Style - APA Sixth Edition:

Paladova, T. A., Prigoda, L. V., \& Maltseva, E. S. (2015, July 15). State funding and budget efficiency of program-focused events of regional industry development. (Z. Čekerevac, Ed.) FBIM Transactions, 3(2), 93-96. doi:10.12709/fbim.03.03.02.11

Style - Chicago Sixteenth Edition:

Paladova, Tatiana A, Ludmila V Prigoda, and Elena S Maltseva. 2015. "State funding and budget efficiency of program-focused events of regional industry development." Edited by Zoran Čekerevac. FBIM Transactions (MESTE) 3 (2): 93-96. doi:10.12709/fbim.03.03.02.11.

Style - GOST Name Sort:

Paladova Tatiana A, Prigoda Ludmila V and Maltseva Elena S State funding and budget efficiency of program-focused events of regional industry development [Journal] // FBIM Transactions / ed. Čekerevac Zoran. - Belgrade : MESTE, July 15, 2015. - 2 : Vol. 3. - pp. 93-96.

Style - Harvard Anglia:

Paladova, T. A., Prigoda, L. V. \& Maltseva, E. S., 2015. State funding and budget efficiency of programfocused events of regional industry development. FBIM Transactions, 15 July, 3(2), pp. 93-96.

Style - ISO 690 Numerical Reference:

State funding and budget efficiency of program-focused events of regional industry development. Paladova, Tatiana A, Prigoda, Ludmila V and Maltseva, Elena S. [ed.] Zoran Čekerevac. 2, Belgrade : MESTE, July 15, 2015, FBIM Transactions, Vol. 3, pp. 93-96. 